Article

\title{
Agricultural Water Allocation under Cyclical Scarcity: The Role of Priority Water Rights
}

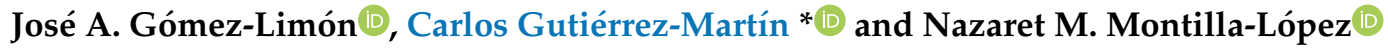 \\ WEARE-Water, Environmental and Agricultural Resources Economics Research Group, \\ Department of Agricultural Economics, Universidad de Córdoba, Campus Rabanales, Ctra. N-IV km 396, \\ E-14014 Córdoba, Spain; jglimon@uco.es (J.A.G.-L.); g02molon@uco.es (N.M.M.-L.) \\ * Correspondence: carlos.gutierrez@uco.es; Tel.: +34-638-909-974
}

Received: 19 May 2020; Accepted: 24 June 2020; Published: 26 June 2020

\begin{abstract}
Water is becoming an increasingly scarce resource worldwide, suggesting that water rationing methods should be revised to improve water allocation efficiency, especially during cyclical scarcity events (droughts). The proportional rule is the most widely used rationing method to allocate water in cases of water scarcity. However, this method fails to achieve Pareto-efficient allocation arrangements. Economic theory and international experience demonstrate that implementing security-differentiated water rights could improve allocative efficiency during cyclical scarcity periods. Moreover, it has been proven that this kind of priority rights regime is an efficient instrument to share risks related to water supply reliability, and can thus be considered as an adaptation measure to climate change. This evidence has enabled the development of an operational proposal for the implementation of security-differentiated water rights in the irrigation sector in Spain, as an alternative to the current rights based on the proportional rule. This proposal draws on the Australian case study, which is the most successful experience worldwide. Nevertheless, the insights obtained from the analysis performed and the proposal for reforming the water rights regime are applicable to any country with a mature water economy.
\end{abstract}

Keywords: water scarcity; water management; water rights; water supply reliability; irrigation agriculture; allocation rules; priority rights; Spain

\section{Introduction}

Water is becoming an increasingly scarce natural resource in many regions worldwide. The driving forces behind this are population growth and economic development, since both factors lead to a growing demand for water-intensive goods and services, most notably agro-food products (irrigation) [1]. As a result, we have witnessed over recent decades a marked increase in global water abstraction and consumption. Within this framework, supply-side measures (i.e., building new infrastructure like reservoirs and waterways to satisfy new human needs) are no longer a viable option in regions with mature water economies, where no further increases in resource availability are feasible either from an economic (prohibitive investment costs) or an environmental (conservation of water-related ecosystems) point of view. In these circumstances, river basins are said to be 'closed' [2], and new demands can only be met by reducing the existing ones through the implementation of so-called demand-side instruments, such as water pricing, water trade (water markets and water banks) or incentivizing water-saving technologies [3,4].

The closure of river basins has become common practice in the Mediterranean and semi-arid climate regions of developed countries such as Australia, Spain, or the United States (specifically western states). One thing all these territories have in common is competitive irrigated agriculture consuming up to $80 \%$ of total water use [5]. As such, there is strong competition for water between 
the irrigation sector and other users (urban consumption, other economic activities such as tourism, and the environment), evidencing the existence of 'structural' or 'permanent' water scarcity. Moreover, structural water scarcity is getting worse because of climate change. IPCC projections [6] for these regions indicate a decrease in precipitation and water availability, while the progressive temperature rise will increase irrigation water needs, resulting in greater demand for irrigation water.

In all these structurally water-scarce regions, water shortages are more severe during drought periods. In these episodes of 'cyclical' water scarcity, demand far exceeds water availability, and competition for the use of the resource becomes acute. Furthermore, according to climate change predictions [6], drought periods in these regions are expected to become more frequent and intense.

When water availability is lower than water demand, resources have to be rationed and allocated among users' needs. This is especially challenging during drought periods when the supply-demand gap or water deficit reaches its highest values [7].

Water is a complex economic good needed for economic activities as an input in many production processes (e.g., irrigation and industry). It also provides social and ecosystem services (e.g., drinking and sanitary water or ecological inflows). For this reason, water usually enjoys a distinctive legal status, managed under the public trust doctrine aimed at ensuring efficiency, equity, and environmental sustainability [8]. Under this doctrine, structural water scarcity is managed through water rights (or water entitlements) granted by a public authority responsible for allocating the average (or normal) water availability among socially recognized users, and preventing those who are not right holders from abstracting and using this resource. Current water rights regimes are often criticized because they are shaped by historical preferences and usage patterns that do not meet the needs of today's society, and they are poorly designed to cope with changing conditions such as new water demands or climate change [7]. All this justifies the need to reform water rights regimes, aiming at a more rational and sustainable allocation of scarce water resources in the long run $[9,10]$.

Water rights regimes, in addition to determining who is allowed to use water resources, also establish how much water is available for each right holder in case of shortages (drought periods), when the total volume of water available is lower than the sum of the water volumes granted by the individual entitlements. Thus, water rights regimes also stipulate which of several existing rationing systems is to be implemented among right holders for scarcity management. Possible alternatives in this regard include proportional sharing or sequences of priority uses, sometimes combined with a water allocations trade. This paper is focused on analyzing these alternative policy options to cope with cyclical water scarcity, when the competition for water is at its most acute and rationing is most challenging [11].

Economics is "the science which studies human behavior as a relationship between ends and scarce means which have alternative uses" [12]. Thus, economics can play a key role in analyzing how scarce water resources ('scarce means') should be allocated among the demands from various users ('alternative uses') considering the desired policy objectives (the 'ends'). This justifies the application of economic theory to the analysis of alternative policy options for water rationing during drought periods.

Within this context, the objective of this paper is twofold. First, we outline a framework for the water allocation instruments and rules that can be implemented during drought periods to ration the scarce available water resources. For this purpose, we rely on economic theory, relating the different rationing alternatives to the policy objectives than can be achieved.

Second, the above-mentioned theoretical framework is used to analyze the water allocation and rationing system currently implemented in the Spanish irrigated agriculture sector. This allows us to explore how these instruments and rules could be improved to minimize drought-driven social welfare losses.

The choice of the case study analyzed here is justified for several reasons. First, because Spanish irrigated agriculture, like any other irrigated agricultural system in the Mediterranean region, is prone 
to be affected by frequent and intense drought episodes, with future projections indicating that this risk is likely to increase due to climate change [13]. Second, because of the importance of this sector in Spain as it covers more than 3.8 million hectares ( $17 \%$ of the national agricultural area), generating a total production valued at around 16 billion Euros annually and employing 415,714 workers [14]. Thus, any water supply gap affecting the irrigation sector entails relevant losses in terms of agricultural income and employment. And third, because there is consistent evidence showing that Spanish irrigators are willing to pay to reduce their exposure to droughts, taking into account the fact that there is no risk management instrument available (e.g., insurance) allowing them to cover potential losses related to water supply gaps [15].

\section{Economic Foundation for Water Allocation Under Cyclical Scarcity}

\subsection{A Flowchart Framing Water Allocation Instruments and Rules}

The main purpose of water policy is (or ought to be) to help ensure that water-related activities lead to a 'socially optimal outcome'. In this sense, it is widely acknowledged that in implementing this kind of policy, policymakers seek to successfully balance two conflicting objectives: economic efficiency and distributional equity. Thus, in order to promote a socially optimal outcome or welfare within this framework, policy design must achieve the appropriate trade-off between efficiency and equity objectives. This trade-off, based on society's concern for both objectives, is (or ought to be) expressed through the policy-makers' guidelines [16].

Establishing the appropriate trade-off between efficiency and equity is the core of normative economics, and it is the starting point of the positive economic analysis aimed at identifying the most suitable policy instruments for implementation in the real world to achieve the socially optimal outcome (i.e., social welfare maximization). Within this policy analysis framework, the water allocation instruments and rules under cyclical scarcity can be framed as shown in Figure 1.

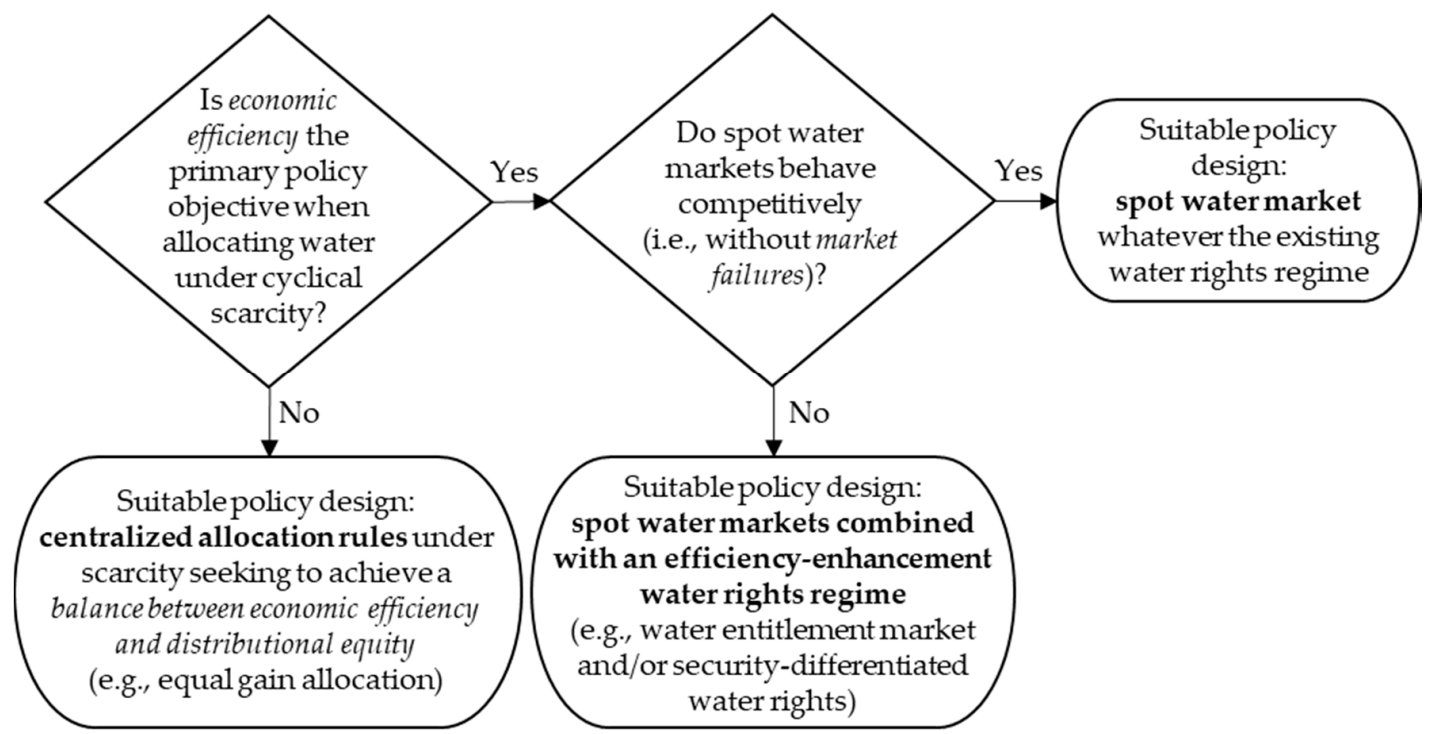

Figure 1. Flowchart framing suitable water allocation instruments and rules under cyclical scarcity.

In sum, the flowchart in Figure 1 shows that if economic efficiency is the primary policy objective when allocating water under cyclical scarcity and competitive spot water markets can be developed in a real setting, this trade-based allocation instrument yields the optimal policy outcome. Under these circumstances, the market can reallocate scarce water resources among users irrespective of their initial allocation (water rights regime), with the final allocation enabling the maximum aggregate net benefit from water use (i.e., economic efficiency) [17]. However, if there are market failures (relevant externalities, high transaction costs, or barriers to trade), spot water markets could fail to achieve 
economic efficiency, with the final outcome depending on the initial allocation of water resources available. Thus, the question of how water rights regimes are defined (i.e., how water is initially allocated) becomes a key issue [18]. In the presence of market failures, spot water markets should be combined with water rights regimes that minimize those failures, enabling the final allocation of scarce resources to enhance economic efficiency (higher aggregate net benefit from water use).

Moreover, policymakers can also consider equity as another relevant policy objective to be achieved when allocating water during drought periods. In this case, policy action based purely on market instruments is not recommended, since trading instruments on their own usually lead to an inequitable final allocation of water, exacerbating income gaps between regions and economic sectors [19]. In light of this circumstance, the public trust doctrine can be justified within the water sector, with the water rights regime being regulated to allow a public authority to allocate scarce water resources based on public interest criteria and ban any possibility of water trade (i.e., the initial water allocation remains unchanged). In this sense, there are several allocation rules with different characteristic properties in terms of efficiency and equity that can be implemented. Depending on the policy guidelines regarding the trade-off between economic efficiency and equity objectives, the most suitable allocation rule can be chosen as the policy option to ration water among right holders under scarcity conditions.

The following subsections provide more detailed explanations justifying the suitability of each policy option suggested.

\subsection{Spot Water Markets as Allocation Instruments}

The market is an economic institution widely used to allocate economic (scarce) goods, including natural resources, among their alternative uses based on a decentralized price mechanism. The widespread use of market instruments is supported by economic theory, more specifically through the First Theorem of Welfare Economics, which states that if there are markets for all commodities and all these markets are competitive, then the equilibrium of the economy is efficient [20]. This theorem explains why water markets are advocated as efficient instruments for water allocation under scarcity settings.

In this sense, it is worth clarifying that the type of efficiency potentially achieved by spot or allocation water markets is Pareto efficiency, also referred to as allocative efficiency. This means that a property of any of the various resource allocation arrangements that could be achieved through these water markets is that there is no other feasible allocation which would make some individuals better off and no individuals worse off. Achieving this kind of efficient arrangement is possible because markets create a system of economic incentives to allocate water to higher value uses through mutually advantageous trade operations for sellers and buyers, at least until the equilibrium price is reached and further gains from trade are exhausted. Within this decentralized allocation framework, the marginal values of all water users became equal to the equilibrium price, maximizing their net benefits, and thus the aggregate net benefit from the use of the water available [21].

Moreover, Pareto-efficient market solutions have two interesting features that are worth pointing out. First, the final allocation arrangements achieved through trade are independent of the initial allocation of resources (i.e., the distribution initially set by water rights) [17]. Second, the equilibrium prices reached are dynamic, always reflecting the full opportunity cost of water (i.e., the scarcity rent). This makes spot water markets flexible economic instruments, which allow a timely, decentralized adaptive management approach for every local situation.

Given all of the above-mentioned characteristics, the economic literature has identified competitive water markets as the most efficient water allocation instruments to cope with water shortage situations (drought periods) [22-24]. They are considered especially suitable for implementation in cases where there is no relevant concern about equity-related objectives or, simply, these objectives are pursued through other, horizontal policies such as taxation and welfare programs targeted at improving social equity. In fact, substantial economic efficiency gains from water trade have been acknowledged in 
empirical analyses from around the world (e.g., [25-27]), including those specifically focused on the irrigation sector (e.g., [28-31]).

In any case, the consideration of spot water markets as efficient allocation instruments during scarcity periods needs to be further examined, taking into account a number of key issues. First, the complex nature of water resources, which creates numerous sources of market failures, meaning that the actual spot water markets allocate resources inefficiently. In this regard, there are two predominant sources of market failure, common to all water markets worldwide [21,32]:

1. Water is used for a wide variety of public purposes (e.g., instream flows for maintaining ecosystems or recreational activities). These water uses are public goods that cannot be exchanged in markets, and thus they have no market price signaling their relative scarcity. This means that the marginal benefits from these uses are understated when allocating water through the markets, leading to the underproduction of these public goods.

2. Market reallocation of water resources usually generates externalities or third-party effects (e.g., changes in the quantity and quality of return flows or economic side-effects in regions selling water). As the level of externalities generated is not controlled by any market equilibrium price, it cannot be concluded that the allocation solutions achieved through trade are efficient.

In the presence of either of these two failures, stand-alone spot water markets are neither efficient nor socially acceptable instruments for managing water resources under shortage scenarios [32].

Second, it also worth pointing out that water market operations involve transaction costs: the costs over and above the market water price that the water buyers must bear when purchasing water allocations, due to water conveyance costs, search and information costs, bargaining and decision costs, and enforcement costs, including contracting $[33,34]$. Depending on the institutional arrangement and the elasticity of supply and demand, these transaction costs can also be borne by water sellers, which would negatively affect their revenues from sales. The existence of transaction costs is relevant for market activity since they involve an inward shift in the demand curve and an outward shift in the supply curve. This results in a reduction of the market activity since the only transfers that take place are those where the differences in marginal values (i.e., potential gains) exceed transaction costs. Therefore, the higher the transaction costs, the thinner the market and the lower the net gains from reallocation [35]. The existence of transaction costs thus affects the final allocations of water, making them more dependent on the initial assignment of resources (i.e., the distribution of water rights), thereby limiting market efficiency [18].

To cope with widespread market failures and high transactions costs, different strategies have been suggested to minimize their efficiency-limiting effects: command-and-control regulations (e.g., setting minimum ecological instream flows), economic incentives (e.g., taxing polluting activities or subsidizing water-saving technologies), or public sector participation in water markets, translating the social values of water into market values. In this paper, however, we focus on how to combine spot water markets with alternative water rights regimes to improve the economic efficiency of water use under cyclical scarcity situations. To this end, we rely on the works of Freebairn and Quiggin [36] and Lefebvre et al. [37], who studied the effects of the implementation of water rights with different levels of supply security as a complement to water markets, showing that these kinds of water rights reduce the effects of market imperfections compared with proportional water rights. This evidence supports the need for the application of water rights regimes based on priority allocation rules as a way of improving economic efficiency under water shortage scenarios.

The third and last key issue regarding the efficiency of spot water markets during scarcity periods is related to society's equity concerns. In this sense, it is worth noting that efficient markets do not necessarily lead to socially optimal water allocation or Pareto-optimality, the best performing allocation arrangement in terms of the social welfare function, where equity concerns are also considered [20]. In fact, the Pareto-efficient allocations achieved through a competitive spot water market may be highly inequitable, meaning that these market solutions may not maximize welfare functions based on value 
judgments which prioritize equity [38]. In cases where the allocation arrangements achieved through market transactions are socially perceived as 'unfair', state intervention is also justified. One policy option is to maintain the market as the water allocation instrument and amend its efficient outcome in welfare terms using income redistribution programs (e.g., through the tax system and welfare state instruments). The other option, as displayed in Figure 1, is to discard the market as an allocation mechanism and replace it with centralized allocation rules (i.e., water rights regime) that are aimed at ensuring the highest possible social welfare associated with the use of water, as explained in the next section.

\subsection{Centralized Allocations Rules}

When policymakers consider not just efficiency but equity too as a relevant policy objective, the revision of centralized allocation rules emerges as an interesting alternative to water markets for improving resource allocation in drought situations. These rules are exogenous regulatory mechanisms through which regulators can alter how water use rights are shared, seeking to achieve the greatest possible social welfare (Pareto-optimality) associated with the use of water [39].

The problem of how to fairly allocate available resources in a system that cannot satisfy all the demands or claims of the beneficiaries is a classic question, which has been widely analyzed in the economic literature as the 'bankruptcy problem'. The original framing of the problem relates to a situation in which several agents claim different amounts of money that together exceed the liquidation value of a bankrupt company, and this liquidation value must be divided among the agents. However, bankruptcy-like problems can be found in many other real-life problems, where the application of this approach has proven suitable. The challenge of water rationing under shortage conditions, seeking a fair allocation of the total water deficit (the difference between the total demand and the available resource) among water rights holders, is one such field of application [40], as has been shown in various empirical studies (e.g., [41-44]).

Within the rationing methods proposed to solve the bankruptcy problem, we can distinguish between symmetric and asymmetric ones. Symmetric methods are those that are based on the 'equal treatment of equals' axiom, which promotes equal shares to equal demands. On the other hand, asymmetric methods are those that do not comply with this axiom, and thus shares are allocated on the basis of priority criteria, whether in relative or absolute terms.

\subsubsection{Symmetric Methods}

Within the symmetric distribution methods, there are three predominant ones. These are the proportional, equal gains, and equal losses methods [45,46]. The proportional $(\mathrm{P})$ method is the best known and it is based on all claimants being assigned an amount (water allocation in our case) proportional to their claim (water rights). In the equal gains method (EG, also called 'uniform gains' or 'constrained equal awards'), all claimants receive the same amount, as long as it does not exceed what is claimed. Similarly, in the equal losses method (EL, also called 'constrained equal losses') all claims are trimmed by the same amount, on the condition that no-one should receive a negative amount.

These three allocation rules (P, EG, and EL) comply with four basic properties or axioms that make them suitable for implementation for agricultural water sharing $[47,48]$ :

1. Consistency, when the rationing method allocates the same volume of water irrespective of whether it is applied to all claimant irrigators at the same time or separately for different subsets of irrigators.

2. Independence of scale, which can be interpreted as independence regarding the unit of measure of the resource rationed (e.g., cubic meters, megaliters, acre-feet, etc.). This implies that any proportional increase in water availability and demands results in the same proportional increase in water allocations. 
3. Composition down (or 'upper composition') is an invariance property regarding changes in the availability of the resource being distributed. This occurs when the individual water allocations are calculated in advance based on the expected water availability, but in the end, there is actually less water to share than initially assumed. In these situations, reapplying a rationing method that complies with this axiom yields the same final allocation arrangement as would have been achieved in a single step if it had initially been implemented based on the actual volume of water available.

4. Composition up (or 'lower composition'). This is similar to the previous one, but this axiom applies when the volume of water initially allocated is lower than the volume of the resource eventually available for sharing. Under these circumstances, the allocation of the additional volume of water available by reapplying a rationing method meeting this property results in the same final allocation arrangement as would have been achieved in the beginning if the initial calculation had been based on the actual amount of water available.

In the literature regarding the allocation of agricultural water, there are a number of empirical studies that analyze the efficiency of symmetric rules. Goetz et al. [49,50] and Martínez and Esteban [51], through applications implemented in three different irrigation districts in Spain, demonstrate that the EG method is more efficient from an economic perspective than the proportional one. However, in both cases, the two symmetric allocation rules considered substantially reduce the economic efficiency compared with market allocation. Similarly, Alarcón et al. [52] compare the proportional and the EL methods with the optimal allocation where total economic loss is minimized (mimicking the results from a competitive spot water market) in another Spanish irrigation district. They conclude that the implementation of the proportional method results in large efficiency losses compared to market allocation. While the market allocation also outperforms the EL method in efficiency terms, the efficiency losses are less than with the proportional method.

All these empirical works also prove that the more heterogeneous the irrigators and the scarcer the water resources, the larger the efficiency losses of the symmetric methods compared to market allocation.

Finally, it is worth citing the work by Madani and Dinar [39], who compare the performance of the proportional and EG methods for groundwater management using a stylized numerical example. Their results differ from previous evidence, showing that the proportional method outperforms the EG method in terms of economic efficiency and equity criteria.

\subsubsection{Asymmetric Methods}

If the axiom of equal treatment of equals is not met, we are dealing with asymmetric rationing methods. In these cases, agents are classified into priority classes according to exogenous criteria, with their demand being met lexicographically following a priority order also set exogenously. That is, the demands of the agents with the highest priority are met first and, once fully satisfied, the remaining resource is allocated to the following agents according to a decreasing priority order criterion [48].

The most asymmetric rule is the full sequential allocation, where every single agent is considered as a different class [53]. This is the theoretical foundation of the prior appropriation doctrine used in the Western United States to define water rights. This doctrine is based on the legal principle expressed by the Latin phrase "qui prior est in tempore, potior est in jure", which means "he/she who is first in time is first in right". Following this doctrine, water right holders in the Western United States are ordered along a line according to the seniority of their rights; the longer the right has existed, the higher the priority assigned to it.

Priority rules can also be established considering a reduced number of priority classes (two or three, for instance, depending on the type of users: urban, environment, and economic activities). In this case, agents in different classes are treated differently according to the priority order criterion, but agents classified in the same priority class are treated under the axiom of equal treatment of equals, using any of the above-mentioned symmetric methods (P, EG, or EL methods). 
Other asymmetric methods include those based on weights indicating the 'relative priority' (as opposed to the 'absolute priorities' outlined in the preceding paragraphs) that should be given to agents [47]. In all cases, each claim is multiplied by the exogenous weights assigned to the agent holding it, and shares are calculated following any rationing method, with the condition that no-one should receive more than his/her claim. Examples of methods that involve this procedure include the weighted proportional method, the weighted gains method, or the weighted losses method.

All these asymmetric methods also meet the four above-mentioned desirable properties for water management; namely, consistency, independence of scale, composition up, and composition down [48].

Calatrava and Garrido [54] provide an example of the implementation of the weighted proportional method within an irrigation district, where ligneous crops are given relative priority over horticultural crops, and the latter over extensive annual crops. These authors demonstrate that this allocation method achieves greater economic efficiency than the proportional one, but lower than market allocation.

\subsubsection{Rationing Methods and Social Choice}

The rationing problem has also been analyzed from the perspective of social choice theory, analyzing the role of asymmetric information in the implementation of allocation rules and the contribution to Pareto-efficient arrangements [55].

In bankruptcy problems, the allocation rules are unequivocally applied to the specific and public demands of each claimant. However, in many other rationing problems, as is the case of water sharing, the demands of the agents involved in the allocation are characterized by asymmetric information since only the claimants know their real needs (the optimal quantities they want to demand). In this context, the rationing rules must comply with the property of strategyproofness, which denotes that agents have a single preference that dominates over all other strategies and that these agents have no incentive to claim more or less than they really need. Of all the symmetric rationing methods discussed above, only the EG method is strategyproof, in addition to complying with the properties of Pareto-efficiency [56]. Likewise, all the above-mentioned asymmetric allocation rules are strategyproof, but none of them are shown to be Pareto-efficient. However, Barberà et al. [57] have developed a sequential rule that fulfills the properties of both strategyproofness and Pareto-efficiency. This asymmetric rule is similar to the EG, except for the fact that the agents, in addition to having different preferences on the quantity of the resource demanded, also have rights over different maximum allotments.

Goetz et al. [50,58] apply the sequential rule proposed by Barberà et al. [57] in two irrigation districts in Spain and compare it with the P and EG methods, providing evidence that this rule is more efficient than the two symmetric ones, especially if there is substantial heterogeneity among irrigators. Nevertheless, they conclude that the allocation obtained by implementing this sequential rule is less efficient than market allocation.

\section{Agricultural Water Management in Spain}

In line with the public trust doctrine, the Spanish Water Law (Royal Legislative Decree 1/2001) establishes that all water resources are considered to lay in the public domain. Thus, the use of water for economic activities requires an administrative concession or water right. These water rights are granted by basin authorities according to the river basin management plans (RBMP), taking into account the rational exploitation of resources (i.e., in relation to average water availability based on current infrastructure like reservoirs and waterways), however, the water rights held do not guarantee the actual availability. Logically, the effective water use by right holders is subject to the actual availability of the resource (i.e., water stored in reservoirs). When there is a water shortage due to hydrological drought events (i.e., below-average levels of water stored), the basin authorities temporarily limit the use of the water legally granted in the water rights, applying a combination of two rationing rules. First, right holders are classified into priority classes depending on the type of water use. Based on general interest criteria, the Spanish Water Law considers urban use (human consumption and industries 
connected to urban supply networks) to be the first priority, followed successively by agricultural uses (irrigation), electric power production, industrial uses, aquaculture, recreational uses, navigation and, finally, other uses not included the aforementioned categories. Therefore, under scarcity conditions (droughts), water allocation in Spain is managed by implementing a priority rule differentiating between types of use. Second, within each priority class, all right holders are rationed using the proportional method (i.e., when the total volume of water available for the class in question, once the demands of higher priority classes have been fully met, is not enough to meet the demands of the right holders).

Table 1 shows the water rights legally granted in the main Spanish river basins, with these rights divided into priority classes: urban, agricultural, and other uses. In this sense, it is worth highlighting the relevance of agricultural use, which accounts for $78.8 \%$ of total water rights at the country level. Furthermore, it can be observed that the river basins with the largest water allocations (Ebro, Duero, and Guadalquivir) are precisely those where irrigation water consumption represents the greatest share of the total, accounting for around $90 \%$ of the total water use in these territories.

Table 1. Water rights granted in the main Spanish river basins ${ }^{1}$.

\begin{tabular}{|c|c|c|c|c|c|c|c|}
\hline \multirow{2}{*}{ River Basin } & \multicolumn{2}{|c|}{ Urban } & \multicolumn{2}{|c|}{ Agricultural } & \multicolumn{2}{|c|}{ Other Uses } & \multirow{2}{*}{$\begin{array}{c}\text { Total } \\
\mathrm{hm}^{3} / \text { year }\end{array}$} \\
\hline & $\mathrm{hm}^{3} /$ year & $\% /$ total & $\mathrm{hm}^{3} /$ year & $\% /$ total & $\mathrm{hm}^{3} /$ year & $\% /$ total & \\
\hline Ebro & 614 & $(7.3 \%)$ & 7679 & $(91.7 \%)$ & 85 & $(1.0 \%)$ & 8378 \\
\hline Guadalquivir & 400 & $(10.6 \%)$ & 3328 & $(88.2 \%)$ & 43 & $(1.2 \%)$ & 3771 \\
\hline Duero & 285 & $(7.6 \%)$ & 3426 & $(91.2 \%)$ & 46 & $(1.2 \%)$ & 3756 \\
\hline Tajo & 994 & $(33.1 \%)$ & 1912 & $(63.7 \%)$ & 96 & $(3.2 \%)$ & 3002 \\
\hline Júcar & 572 & $(20.5 \%)$ & 2182 & $(78.2 \%)$ & 35 & $(1.3 \%)$ & 2789 \\
\hline Guadiana & 254 & $(10.8 \%)$ & 2022 & $(85.7 \%)$ & 82 & $(3.5 \%)$ & 2359 \\
\hline Segura & 238 & $(14.9 \%)$ & 1353 & $(84.6 \%)$ & 9 & $(0.6 \%)$ & 1600 \\
\hline Andalusian Mediterranean & 279 & $(25.3 \%)$ & 770 & $(70.0 \%)$ & 51 & $(4.6 \%)$ & 1100 \\
\hline Other river basins & 1948 & $(48.2 \%)$ & 1595 & $(39.5 \%)$ & 500 & $(12.4 \%)$ & 4042 \\
\hline Total Spain & 5584 & $(18.1 \%)$ & 24,266 & $(78.8 \%)$ & 948 & $(3.1 \%)$ & 30,797 \\
\hline
\end{tabular}

Source: Dirección General del Agua and Centro de Estudios Hidrográficos [59]. ${ }^{1} 1 \mathrm{hm}^{3}$ equals $1 \mathrm{Mm}{ }^{3}$, or 1 GL, or 810.71 acre-feet.

In Spain, the concession of new water rights by the basin authorities is only possible if two conditions are met: (i) the new water uses contribute to the general interest criteria set in the RBMP, and (ii) the new water demand can be satisfied in accordance with the reliability criteria set at country level, taking into account the actual availability of water resources in each basin (i.e., based on climate, geography, and available infrastructure for water storage and transport). This second requirement is a constraint on many Spanish basins that have been officially declared 'closed' since there are no further possibilities of increasing the water supply.

Considering the requirements regarding supply reliability, all water rights granted can be fully satisfied in 'normal' (i.e., close to average) hydrological years. In fact, it is only in cases of prolonged drought episodes that there are problems meeting all these demands, making it necessary to ration water allocations for some users, starting with the lowest priority uses. In this regard, taking into account the legally established priority of urban over agricultural uses, in river basins where a major share of water rights is assigned to agricultural use, the supply of water for urban use is practically assured even in the most extreme drought scenarios. Thus, in situations of cyclical scarcity caused by hydrological droughts, water supply restrictions almost exclusively affect allocations for agricultural purposes.

In accordance with the European Water Framework Directive, Spanish law also establishes that basin authorities must approve drought management plans (DMP) as a complement to their RBMP. These plans specify the way in which water resources must be managed and allocated during periods of scarcity. For this purpose, a set of drought indicators have been defined to provide information about the current scarcity scenario [60]: normality (absence of scarcity), pre-alert (moderate scarcity), Alert (severe scarcity), and emergency (extreme scarcity). If the indicators point to any scenario other 
than Normality, the basin authority must enact the drought management measures set out in the DMP to minimize the environmental, economic, and social impacts of scarcity.

In the event of alert or emergency scenarios, the basin authority reduces water allocations for irrigation, with all agricultural right holders receiving equal rations determined using the proportional method as water allocation rule. Thus, allocations to all irrigators within the same water use system (management units within river basins) are proportionally reduced to maintain the reserves needed to meet higher priority uses (i.e., urban use). The implementation of this proportional rule, however, does not produce an economically efficient distribution of the water available for the agricultural sector since the irrigators being allocated the rations are quite heterogeneous. This heterogeneity is mainly due to the varying pedoclimatic conditions found within a single water use system (e.g., the Regulación General water use system in the Guadalquivir basin comprises 723,951 irrigated hectares), although differences in farm size and farmers' psychological characteristics (e.g., risk aversion) may also have an influence. In these circumstances, proportional water rationing leads to quite different impacts on farmers depending on their water productivity. In fact, the losses caused by water supply cuts differ notably between extensive and intensive agriculture: farmers dedicated to the extensive production of herbaceous crops (cereals, industrial crops, etc., with low marginal productivity of water) face moderate losses, while the losses for farmers producing intensive crops (vegetables or fruits, with high marginal productivity of water) are potentially very high. This explains why this allocation method is not optimal from an economic point of view since it fails to minimize the losses derived from water scarcity.

In an attempt to partially solve this inefficient allocation during cyclical scarcity periods, spot water markets and public water banks were made legal in Spain in 1999. However, their performance as a water reallocation instrument has been rather disappointing [61]. In fact, water trading has been active only during drought periods, and even under these severe scarcity situations, market activity accounted for less than $1.0 \%$ of total water use. The most intense trading occurred during 2007, an extremely dry year, when water exchanges accounted for $248 \mathrm{Mm}^{3}(0.78 \%$ of total water use in Spain for this year, although the share of water traded reached $4 \%$ for some basins in southeastern Spain), with the water price in these two market instruments ranging from 0.12 to 0.27 Euros $/ \mathrm{m}^{3}[62,63]$. These figures show the narrowness of the water markets in Spain, suggesting that transaction costs and multiple barriers to trade are hampering their effective functioning.

Moreover, following the 2019 general election in Spain, a new left-wing coalition government was formed. This new government is founded on a coalition agreement document signed by the parties sharing the political power, which sets the policy guidelines for the current legislative term. This agreement establishes the political intention to ban water markets on the basis that water "should not be considered a commercial asset". Thus, a reform of the Spanish Water Act is expected, forbidding water trade among water users (some doubts remain regarding the public water banks operating in Spain during droughts). This legislative reform has not been accomplished yet, and the policy agenda in the short-term has changed because of issues related to the Covid-19 pandemic. In any case, the Spanish government still intends to launch this water policy reform and approve it before the end of the current legislative term in 2022. This expected legal change triggers the need for new alternative designs of water rights regimes to prevent the efficiency losses caused by the implementation of the proportional rule during drought events.

\section{Alternative Water Allocation Methods: The International Experience}

The Western United States and Australia provide valuable examples regarding agricultural water management. Both countries share some key characteristics with Spain (semi-arid climates, a mature water economy, a large and competitive irrigated agriculture sector, and severe cyclical water scarcity problems) [5]. As such, they can be considered as suitable benchmarks to learn about allocating agricultural water during drought periods. This section briefly describes the asymmetric allocation 
rules implemented in each of these countries, before critically analyzing their pros and cons, as well as their suitability for potential implementation in Spain.

\subsection{Western United States}

In the western United States, water rights are mainly governed by the 'prior appropriation doctrine' (PAD), which establishes a fully sequential allocation method. The priority is thus determined by the chronological order in which the rights were granted, from the most senior (the longest-standing rights have the highest priority) to the most junior (the most recent have the lowest priority).

In addition to appropriative water rights, there are two other minority types of water rights in the western United States: 'pueblo' rights and 'federal reserved' rights. The first are water rights initially granted to the Spanish and Mexican 'pueblos' (settlements), and later legally recognized to preserve the traditional water rights held by some cities (e.g., Los Angeles) and native American communities (e.g., New Mexico Pueblos) [64,65]. The federal reserved rights are established when the U.S. federal government reserves public land for uses such as Indian reservations, military reservations, or national parks, with each reservation being granted the water rights needed to satisfy the purposes for which it is created [66]. Moreover, riparian water rights are also used in the states on the West Coast (California, Oregon, and Washington) and more humid parts of the Dakotas, Nebraska, Kansas, Oklahoma, and Texas.

The origin of the PAD dates back to the settlement of the American West, where it was used as a simple and efficient way to allocate water consistent with the Ricardian theory of land rent. Indeed, at the time, this doctrine contributed to an efficient allocation of water resources, since the first lands to be irrigated (thus holding more senior rights) were likely be the most productive and profitable ones. However, more than a century later, the most profitable uses of water are not necessarily those that hold the most senior water rights. For this reason, water allocations based on prior appropriation today have drawbacks from the point of view of economic efficiency [67]. Moreover, PAD-based water rights generate heterogeneity in risk-sharing among water users (the more junior right holders run a higher risk of receiving insufficient allocations), which may also contribute to an economically inefficient allocation of water [68].

To minimize the aforementioned inefficiency problems, water rights in the western United States are not tied to the land, with existing spot and permanent water markets allowing allotments and rights transactions, respectively. However, in most of these states, there are institutional barriers to the transfers of water rights in order to prevent third-party effects, which limit the allocative role of the market and, thus, economic efficiency [69].

Water rights in the western United States are also governed by the continuous beneficial use doctrine ('use it or lose it'), which establishes that these rights remain in force only as long as the beneficial use continues. Nevertheless, the application of this doctrine does not always contribute to an efficient allocation of water, given that it may encourage excessive water consumption aimed at maintaining the right. Furthermore, it can also lead to inefficiency if right holders intensively use water for uses legally considered 'beneficial', but with low marginal value [70].

\subsection{Australia}

The most noteworthy type of water rights in Australia are the security-differentiated priority rights which have been in place in the state of Victoria since 1994, and New South Wales (NSW) since 2000. In the rest of Australia, agricultural water is allocated based on the proportional rule.

In these two southern Australian states, agricultural water allocation follows a two-step procedure. First, rights are ordered according to their priority level. Second, the amount of water available for each priority class is shared out through proportional rationing. The implementation of this allocation mechanism involves two types of water rights for agricultural uses with different levels of security (i.e., reliability): high-priority and low-priority rights, although they have different names according to the state [71]. For instance, in NSW, high-priority water rights (officially, 'high-security access licenses') 
account for $9 \%$ of total rights granted for agricultural uses, with the remaining $91 \%$ being low-priority rights or 'general-security access licenses'. The estimated reliability of agricultural high-security access licenses in NSW is 95-97\%, meaning that farmers can expect to receive their full allocations at least 95 years out of 100 . On the other hand, the average reliability of general-security access licenses is around $70 \%[71,72]$.

The water allocation procedure starts at the beginning of the season, when high-priority right holders are allocated 100\% (95\% in NSW) of the nominal quantity established, while those with low-priority rights are assigned only a small percentage of the quantity established in their rights. Over the course of the irrigation season, the water allocated to the latter type of rights is increased depending on the actual water availability, following a proportional rule. In the event that there is not enough water available at the beginning of the year to provide full allocations to high-priority rights (in extreme drought situations), the available water is shared proportionally among the high-priority rights but no water is allocated to low-priority ones [73].

It is also worth commenting that once the water has been allocated, there are no restrictions on reallocating the resource through the existing spot water market, which allows water transfers from low to high value uses between any type of right holder and across states [74]. Moreover, in Australia there is a permanent or water entitlement market that facilitates the transition towards different farming systems (e.g., change in farm size or crop mix) or just makes it easier to leave the farm sector [74]. Both markets have become quite active, with significant improvements in water property rights, trading rules, and market information, as well as reduced transaction costs over time. As a result, in an average year, around 30\% of the announced water allocations and $10 \%$ of water entitlements are traded, facilitating economic efficiency in the short and the long run [75].

\subsection{Pros and Cons of the Priority Allocation Methods}

Water rationing methods based on priority levels have a series of pros and cons which merit analysis before their implementation in a real-world setting.

The main advantages are explained by Freebairn and Quiggin [36] and Lefebvre et al. [37], who argue that a water rights regime with different levels of priority is an interesting alternative for the allocation of water resources within the agricultural sector since it enables more efficient risk-sharing. This allocation mechanism can be used to offer irrigators a portfolio of different water rights establishing different priority levels, suited to their particular circumstances (vulnerability to water supply gaps and risk aversion). For instance, those irrigators running intensive high-value crops could reduce the risk related to water reliability by obtaining high-priority rights, with this risk then being transferred to lower priority right holders, who are better positioned to assume this risk (e.g., farmers with extensive annual crops). This mechanism to transfer water supply risk is much easier to implement than other risk transfer instruments, such as hydrological drought insurance or water options markets.

Moreover, this water rights regime reduces the number of transactions needed in the spot water markets, with the consequent reduction in transaction costs. Thus, the efficient risk-sharing arrangement generated by this regime also results in improved economic efficiency. This is especially relevant in countries where spot water markets have high transaction costs but low volumes of trade activity.

Finally, it is also worth noting that in addition to the above-mentioned short-term advantages, it has been observed that security-differentiated water rights offer a series of long-term benefits. The improvement in the reliability of supply for higher priority right holders enables them to invest in irrigation infrastructure and to transition towards higher added-value farming systems [76,77]. In this sense, it should also be pointed out that high-priority rights can facilitate investments since they act as capital assets that can be held as collateral to secure bank loans [37].

By contrast, it is important to highlight the potential drawbacks of a water rights regime with different levels of priority. First, the configuration of efficient portfolios of water rights requires the implementation of a flexible mechanism allowing users to modify the mix of different priority rights they 
hold (e.g., permanent or water rights market). These mechanisms usually involve significant transaction costs, limiting the efficiency improvements that can be achieved by any security-differentiated allocation method [78].

In this sense, it has been suggested that the most suitable design for priority-differentiated rights is the one based on two priority classes (as in Victoria and NSW), since by combining two types of priority rights water users can achieve any desired level of reliability, while minimizing the transaction costs related to the dynamic adaptation to the right mixes [79].

Likewise, it must be noted that the counterpart to the improvement in the supply reliability obtained by higher priority right holders is the loss of security for the rest of the water users. Thus, if there is no agreement as to some type of compensation from 'reliability winners' to 'reliability losers', the introduction of security-differentiated water rights could be politically and socially controversial.

\section{A Proposal for an Alternative Allocation Method in the Spanish Irrigation Sector}

The above analysis supports the reform of the agricultural water rights regime in Spain, with a shift away from the proportional allocation rule currently in force towards a priority rule allowing the implementation of security-differentiated water rights. Next, an operational proposal is introduced, specifying the characteristics that, a priori, can be considered more suitable for the Spanish case:

- $\quad$ Types of security-differentiated water rights and rationing rules for agricultural use: Two priority classes are proposed, distinguishing between high-security or 'priority rights' and low-security or 'ordinary water rights'. The rationing method applicable during scarcity periods would be similar to the one implemented in Australia, based on a combination of priority allocation between priority classes and proportional allocation within each class.

- Assignment of priority rights: The priority rights would be granted by the basin authorities, who would be responsible for ensuring the water supply to the right holders according to the RBMP approved.

- Initial distribution of priority rights: Considering the fact that most of the Spanish basins are closed, the proposed reform cannot increase the total amount of water granted through water rights. Therefore, it is proposed that all existing water rights should automatically be converted into ordinary ones, and that only a certain share of these existing rights should be allowed to be upgraded into priority rights through an auction procedure. In this sense, we suggest that only $10 \%$ of current ordinary rights in each water use system should be upgraded into priority rights, in order not to have an excessively adverse effect on the reliability of the remaining ordinary ones. The assignment of priority rights could be carried out through a uniform-price sealed-bid auction [80] considering the right holders' willingness to pay measured as a surcharge on the annual regulation tariff (canon de regulación) currently paid to the river basin authorities to finance the water storing and transport services provided by these public agencies. This additional public income would contribute to improving the public supply services provided, especially those related to the reliability of ordinary rights.

- Duration of the upgrade into priority rights: In line with the current legal framework in Spain (whereby water resources are publicly owned and water rights are granted by a public authority for a limited time, with a formal renewal subsequently required to continue using the water), it is proposed that those who win the bid in the auction procedure can hold priority rights for the next 20 years. This is considered a reasonable length of time to enable long-term investment planning in the agricultural sector (fruit orchards, irrigation technology, or specific agricultural machinery). If the water rights were legally renewed before the end of this term, the length of the priority rights would be subject to the renewal of the water rights (i.e., in no case would the assignment of priority rights imply the tacit renewal of concessional rights). In this way, the public assignment of water rights based on public interest would be preserved. 
- Dynamics of the priority rights: After the initial assignment of priority rights, priority right holders would have the possibility of renouncing those rights (i.e., downgrading their priority rights into ordinary rights and stopping paying the surcharge on the annual regulation tariff). This downgrade should be done during the last month of any hydrological year (September). In this way, a reserve of priority rights could be established in each water use system, and the available priority rights could be auctioned again during the first month of the hydrological year (October). This alternative to the water right market is chosen for two reasons: i) it is expected to reduce transaction costs (addressing efficiency concerns), and ii) to preserve public interest (equity concerns).

In order to further clarify the proposal developed, Table 2 shows the main features of the current and the proposed water rights regimes for the Spanish irrigation sector.

Table 2. Current vs. proposed water rights regimes for the Spanish irrigation sector.

\begin{tabular}{|c|c|c|}
\hline Feature & Current Water Rights Regime & Proposed Water Rights Regime \\
\hline Types of water right & Ordinary & Priority and ordinary \\
\hline Allocation rule & Proportional & $\begin{array}{l}\text { Combination of priority allocation between } \\
\text { types of water rights and proportional } \\
\text { allocation within each type }\end{array}$ \\
\hline Distribution of water rights & $\begin{array}{l}\text { Granted at the discretion of the basin } \\
\text { authority, based on public interest criteria }\end{array}$ & $\begin{array}{l}\text { Priority right can be obtained only by current } \\
\text { (ordinary) water right holder through } \\
\text { uniform-price sealed-bid auctions }\end{array}$ \\
\hline Duration of water right & 75 years & $\begin{array}{c}75 \text { years for ordinary rights and } 20 \text { years } \\
\text { for priority rights }\end{array}$ \\
\hline Dynamics & $\begin{array}{l}\text { Virtually automatic renovation of water } \\
\text { rights for new 75-year periods }\end{array}$ & $\begin{array}{l}\text { After the 20-year period, priority rights became } \\
\text { ordinary rights again. Possibility of renouncing } \\
\text { priority rights and subsequent auction for } \\
\text { allocation to other right holders }\end{array}$ \\
\hline Fees & $\begin{array}{l}\text { Annual regulation tariff for water storing } \\
\text { and transport services provided } \\
\text { by the basin authority }\end{array}$ & $\begin{array}{l}\text { Surcharge on the annual regulation tariff for } \\
\text { priority water rights and a reduction in the tariff to } \\
\text { be paid by ordinary right holders }\end{array}$ \\
\hline
\end{tabular}

Another suggestion worth considering is that the new water rights regime proposed should allow individual rights to be defined as a combination (portfolio) of ordinary and priority rights (e.g., with $30 \%$ of the rights being priority and the remaining $70 \%$ ordinary). This would make it easier to engage collective users, such as the irrigators' associations (comunidades de regantes) that hold a single concessional right to supply water to a large number of farmers. Thus, by defining the water rights as portfolios, irrigators' associations could internally implement differential allocation rules according to the varying preferences of their members.

Finally, it should be noted that the above-mentioned proposal, which aims to strike a balance between the two main objectives of water policy (efficiency and equity), has the advantage of being compatible with current Spanish water legislation. In fact, the changes needed to implement the proposed reform could be easily done by updating the RBMP and DMP, where priority uses and allocation rules are defined for each basin.

Furthermore, another notable feature of this new water rights regime is that it acts as a complement to the spot water market already operating in Spain as instruments improving economic efficiency. If water markets were to be banned, as proposed by the new government, the proposal of security-differentiated water rights could be even more appealing since this instrument would be considered as a substitute mechanism providing water right holders the flexibility to adapt to the market and climate change.

The only drawback of the proposal is that the introduction of the priority rights would lead to a deterioration in the security of ordinary rights, which would provoke opposition from affected right holders if they are not properly compensated. In order to minimize this problem, it is suggested that the additional income generated through the surcharge on the annual regulation tariff to be paid by priority right holders should go towards improving the supply reliability of affected right holders, financing negotiated infrastructure, and funding management mechanisms. 
Finally, it is also worth noting that the auction procedure suggested for upgrading into priority rights can be considered as a partially-market-based allocation of water rights, and thus could be contested by those who criticize the use of economic instruments as an alternative to the public sector action in the allocation and management of water resources [81,82]. This a sensitive topic in Spain where there is a strong social and political debate about the implementation of economic instruments to improve economic efficiency and allocative equity in water use, since water is a resource laying in the public domain (i.e., public-owned). In fact, some social and political actors see the implementation of these instruments as part of a wider project of 'privatization' and 'commodification' of water that favor the interests of some concrete agents, instead of the public interest they supposedly promote $[83,84]$. This circumstance calls for further discussion of the proposal introduced aiming at reaching the political consensus needed for the success of this policy reform. In this sense, it is suggested that the auction procedure considers some legal constraints leading to a socially optimal outcome. Thus, this allocation procedure makes it possible to contribute positively to the achievement of public interest objectives taking into account interregional and intersectoral related issues [85].

\section{Conclusions}

Water is getting scarcer in most of the Mediterranean and semi-arid regions around the world, since the demand for this resource is growing while its availability is declining due to climate change. Thus, water rationing methods should be revised to improve water allocation efficiency, especially during cyclical scarcity events (i.e., droughts). The proportional rule is the most widely used rationing method to allocate water in water scarcity scenarios. However, this method fails to achieve Pareto-efficient allocation arrangements when there is substantial heterogeneity among water rights holders (i.e., different marginal water productivity) and allocation water markets are narrow or simply nonexistent. In such cases, implementing security-differentiated water rights could improve allocative efficiency during cyclical scarcity periods.

Water management in Spain is affected by the aforementioned circumstances and is thus a good example of a case where the implementation of security-differentiated water rights could improve water efficiency during drought events. The reform of the water rights regime is particularly appealing in Spain given the anticipated ban on water markets. Notwithstanding, the insights obtained from the analysis performed in this paper are also applicable to any country with a mature water economy.

It has been evidenced that security-differentiated water rights are an efficient instrument to share risks related to water supply reliability. This is a growing concern among water rights holders given the increasing uncertainty in water supply due to climate change. Thus, the proposed change in the water rights regime can also be considered as an adaptation measure to climate change, one which is especially suitable when other alternative instruments to manage supply failure risks, such as drought insurance schemes or water options markets, have not yet been developed.

The proposal for reforming the water rights regime in Spain is primarily based on the Australian case study, since this has proved to be the most successful experience worldwide. Moreover, the two countries share some common features, especially relating to their competitive irrigated agricultural sectors that account for more than $80 \%$ of total water use. In any case, further research is needed to refine the implementation of the security-differentiated water rights regime proposed here. Indeed, this proposal is just the first step within a longer research project. The next step is expected to involve more in-depth examination in a discussion group including water managers and relevant stakeholders (irrigators, environmental groups, etc.) to fine-tune as necessary the key features (e.g., the percentage of current water rights that should be upgraded into priority rights, the rules guiding the auction procedure, the duration of priority rights upgrade, or the end use of the additional income generated by priority rights). This debate will enable the definition of the operational implementation mechanisms (policy alternatives) for reforming the water rights regime in Spain, which should be ex-ante evaluated using simulation modeling based on mathematical programming techniques. This impact assessment will provide guidelines for policy design aimed at identifying 
the most suitable option for implementation. Finally, the chosen policy alternative should also be empirically tested in a real-world setting, implementing it as a pilot case study in a Spanish river basin before full-scale implementation at the national scale. This entire procedure will help to guarantee the success of the policy reform proposed.

Nevertheless, it is worth remarking that the insights obtained from the analysis performed and the proposal for reforming the water rights regime are applicable to any country with a mature water economy. Thus, this paper encourages further debates elsewhere regarding how alternative water rights regimes could enhance water management (water rationing) during cyclical scarcity periods.

Author Contributions: Conceptualization, J.A.G.-L. and C.G.-M.; formal analysis, J.A.G.-L., C.G.-M., and N.M.M.-L.; writing-original draft preparation, J.A.G.-L., C.G.-M., and N.M.M.-L.; writing-review and editing, J.A.G.-L., C.G.-M., and N.M.M.-L.; supervision, J.A.G.-L. All authors have read and agreed to the published version of the manuscript.

Funding: This research and the APC was funded by the Spanish Ministry of Science, Innovation, and Universities (MCIU) and the European Regional Development Fund (ERDF) through the research project IRRIDROUGHT (RTI2018-095407-B-I00). These funding institutions had no involvement in the conduct of the research nor the preparation of the paper.

Conflicts of Interest: The authors declare no conflict of interest.

\section{References}

1. Distefano, T.; Kelly, S. Are we in deep water? Water scarcity and its limits to economic growth. Ecol. Econ. 2017, 142, 130-147. [CrossRef]

2. Molle, F.; Wester, P.; Hirsch, P. River basin closure: Processes, implications and responses. Agric. Water Manag. 2010, 97, 569-577. [CrossRef]

3. Lago, M.; Mysiak, J.; Gómez, C.M.; Delacámara, G.; Maziotis, A. Use of Economic Instruments in Water Policy: Insights From International Experience; Springer: Cham, Switzerland, 2015. [CrossRef]

4. Gómez-Gómez, C.M.; Pérez-Blanco, C.; Adamson, D.; Loch, A. Managing water scarcity at a river basin scale with economic instruments. Water Econ. Policy 2018, 4, 1750004. [CrossRef]

5. Berbel, J.; Esteban, E. Droughts as a catalyst for water policy change. Analysis of Spain, Australia (MDB), and California. Global Environ. Change 2019, 58, 101969. [CrossRef]

6. IPCC (Intergovernmental Panel on Climate Change). Climate Change 2014: Impacts, Adaptation, and Vulnerability. Part. A: Global and Sectoral Aspects. Contribution of Working Group II to the Fifth Assessment Report of the Intergovernmental Panel on Climate Change; Cambridge University Press: Cambridge, UK, 2014.

7. OECD (Organisation for Economic Co-Operation and Development). Water Resources Allocation. Sharing Risks and Opportunities; OECD Publishing: Paris, France, 2015. [CrossRef]

8. Rogers, P.; de Silva, R.; Bhatia, R. Water is an economic good: How to use prices to promote equity, efficiency, and sustainability. Water Policy 2002, 4, 1-17. [CrossRef]

9. Hodgson, S. Modern Water Rights: Theory and Practice; Food and Agriculture Organization (FAO): Rome, Italy, 2006.

10. Bruns, B.R.; Ringler, C.; Meinzen-Dick, R.S. Water Rights Reform: Lessons for Institutional Design; International Food Policy Research Institute (IFPRI): Washington, DC, USA, 2005. [CrossRef]

11. OECD (Organisation for Economic Co-Operation and Development). Mitigating Droughts and Floods in Agriculture. Policy Lessons and Approaches; OECD Publishing: Paris, France, 2016. [CrossRef]

12. Robbins, L. An Essay on the Nature and Significance of Economic Science, 3rd ed.; Macmillan: London, UK, 1983.

13. Bisselink, B.; Bernhard, J.; Gelati, E.; Adamovic, M.; Guenther, S.; Mentaschi, L.; De Roo, A. Impact of a Changing Climate, Land Use, and Water Usage on Europe's Water Resources: A Model. Simulation Study; Publications Office of the European Union: Luxembourg, 2018. [CrossRef]

14. MAPA (Ministerio de Agricultura Pesca y Alimentación). Anuario de Estadística Ministerio de Agricultura Pesca y Alimentación 2018; MAPA: Madrid, Spain, 2019.

15. Guerrero-Baena, M.D.; Villanueva, A.J.; Gómez-Limón, J.A.; Glenk, K. Willingness to pay for improved irrigation water supply reliability: An approach based on probability density functions. Agric. Water Manag. 2019, 217, 11-22. [CrossRef]

16. Myles, G.D. Public Economics; Cambridge University Press: Cambridge, UK, 1995. 
17. Coase, R.H. The problem of social cost. J. Law Econ. 1960, 3, 1-44. [CrossRef]

18. Griffin, R.C. The welfare analytics of transaction costs, externalities, and institutional choice. Am. J. Agric. Econ. 1991, 73, 601-614. [CrossRef]

19. Bourgeon, J.-M.; Easter, K.W.; Smith, R.B.W. Water markets and third-party effects. Am. J. Agric. Econ. 2008, 90, 902-917. [CrossRef]

20. Gravelle, H.; Rees, R. Microeconomics; Pearson: Essex, UK, 2004.

21. Griffin, R.C. Water Resource Economics: The Analysis of Scarcity, Policies, and Projects; The MIT Press: Cambridge, MA, USA, 2006.

22. Bjornlund, H. Efficient water market mechanisms to cope with water scarcity. Int. J. Water Resour. Dev. 2003, 19, 553-567. [CrossRef]

23. Debaere, P.; Richter, B.D.; Davis, K.F.; Duvall, M.S.; Gephart, J.A.; O’Bannon, C.E.; Pelnik, C.; Powell, E.M.; Smith, T.W. Water markets as a response to scarcity. Water Policy 2014, 16, 625-649. [CrossRef]

24. Alarcón, J.; Juana, L. The water markets as effective tools of managing water shortages in an irrigation district. Water Resour. Manag. 2016, 30, 2611-2625. [CrossRef]

25. Hearne, R.R.; Easter, K.W. The economic and financial gains from water markets in Chile. Agric. Econ. 1997, 15, 187-199. [CrossRef]

26. Brooks, R.; Harris, E. Efficiency gains from water markets: Empirical analysis of Watermove in Australia. Agric. Water Manag. 2008, 95, 391-399. [CrossRef]

27. Gohar, A.A.; Ward, F.A. Gains from expanded irrigation water trading in Egypt: An integrated basin approach. Ecol. Econ. 2010, 69, 2535-2548. [CrossRef]

28. Dinar, A.; Letey, J. Agricultural water marketing, allocative efficiency, and drainage reduction. J. Environ. Econ. Manag. 1991, 20, 210-223. [CrossRef]

29. Arriaza, M.; Gómez-Limón, J.A.; Upton, M. Local water markets for irrigation in southern Spain: A multicriteria approach. Aust. J. Agric. Resour. Econ. 2002, 46, 21-43. [CrossRef]

30. Pujol, J.; Raggi, M.; Viaggi, D. The potential impact of markets for irrigation water in Italy and Spain: A comparison of two study areas. Aust. J. Agric. Resour. Econ. 2006, 50, 361-380. [CrossRef]

31. Gómez-Limón, J.A.; Martínez, Y. Multi-criteria modelling of irrigation water market at basin level: A Spanish case study. Eur. J. Oper. Res. 2006, 173, 313-336. [CrossRef]

32. Griffin, R.C.; Peck, D.E.; Maestu, J. Myths, principles and issues in water trading. In Water Trading and Global Water Scarcity: International Experiences; Maestu, J., Ed.; Routledge: London, UK, 2013; pp. 1-14. [CrossRef]

33. McCann, L.; Easter, K.W. A framework for estimating the transaction costs of alternative mechanisms for water exchange and allocation. Water Resour. Res. 2004, 40, W09S0901. [CrossRef]

34. Garrick, D.; Whitten, S.M.; Coggan, A. Understanding the evolution and performance of water markets and allocation policy: A transaction costs analysis framework. Ecol. Econ. 2013, 88, 195-205. [CrossRef]

35. McCann, L.; Garrick, D. Transaction costs and policy design for water markets. In Water Markets for the 21st Century: What Have We Learned? Easter, K.W., Huang, Q., Eds.; Springer: New York, NY, USA, 2014; pp. 11-34. [CrossRef]

36. Freebairn, J.; Quiggin, J. Water rights for variable supplies. Aust. J. Agric. Resour. Econ. 2006, 50, $295-312$. [CrossRef]

37. Lefebvre, M.; Gangadharan, L.; Thoyer, S. Do security-differentiated water rights improve the performance of water markets? Am. J. Agric. Econ. 2012, 94, 1113-1135. [CrossRef]

38. Poddar, R.; Qureshi, M.E.; Shi, T. A comparison of water policies for sustainable irrigation management: The case of India and Australia. Water Resour. Manag. 2014, 28, 1079-1094. [CrossRef]

39. Madani, K.; Dinar, A. Exogenous regulatory institutions for sustainable common pool resource management: Application to groundwater. Water Resour. Econ. 2013, 2, 57-76. [CrossRef]

40. Zarezadeh, M.; Mirchi, A.; Read, L.; Madani, K. Ten bankruptcy methods for resolving natural resource allocation conflicts. In Water Diplomacy in Action. Contingent Approaches to Managing Complex Water Problems; Islam, S., Madani, K., Eds.; Anthem Press: London, UK, 2017; pp. 37-50.

41. Ansink, E.; Weikard, H.-P. Sequential sharing rules for river sharing problems. Soc. Choice Welfare 2012, 38, 187-210. [CrossRef]

42. Mianabadi, H.; Mostert, E.; Zarghami, M.; van de Giesen, N. A new bankruptcy method for conflict resolution in water resources allocation. J. Environ. Manag. 2014, 144, 152-159. [CrossRef] 
43. Sechi, G.M.; Zucca, R. Water resource allocation in critical scarcity conditions: A bankruptcy game approach. Water Resour. Manag. 2015, 29, 541-555. [CrossRef]

44. Wickramage, H.M.; Roberts, D.C.; Hearne, R.R. Water allocation using the bankruptcy model: A case study of the Missouri River. Water 2020, 12, 619. [CrossRef]

45. Herrero, C.; Villar, A. The three musketeers: Four classical solutions to bankruptcy problems. Math. Soc. Sci. 2001, 42, 307-328. [CrossRef]

46. Aumann, R.J.; Maschler, M. Game theoretic analysis of a bankruptcy problem from the Talmud. J. Econ. Theory 1985, 36, 195-213. [CrossRef]

47. Thomson, W. Axiomatic and game-theoretic analysis of bankruptcy and taxation problems: A survey. Math. Soc. Sci. 2003, 45, 249-297. [CrossRef]

48. Moulin, H. Priority rules and other asymmetric rationing methods. Econometrica 2000, 68, 643-684. [CrossRef]

49. Goetz, R.-U.; Martínez, Y.; Rodrigo García, J. Eficiencia de las reglas de asignación de agua en el regadío: Asignación a través de mercados, de la regla proporcional y de la regla uniforme. Econ. Agrar. Recur. Nat. 2005, 5, 115-138. [CrossRef]

50. Goetz, R.-U.; Martínez, Y.; Xabadia, À. Efficiency and acceptance of new water allocation rules-The case of an agricultural water users association. Sci. Total Environ. 2017, 601, 614-625. [CrossRef]

51. Martínez, Y.; Esteban, E. Social choice and groundwater management: Application of the uniform rule. Cienc. Investig. Agrar. 2014, 41, 153-162. [CrossRef]

52. Alarcón, J.; Garrido, A.; Juana, L. Managing irrigation water shortage: A comparison between five allocation rules based on crop benefit functions. Water Resour. Manag. 2014, 28, 2315-2329. [CrossRef]

53. Osório, A. A sequential allocation problem: The asymptotic distribution of resources. Group Decis. Negot. 2017, 26, 357-377. [CrossRef]

54. Calatrava, J.; Garrido, A. Difficulties in adopting formal water trading rules within users' associations. J. Econ. Issues 2006, 40, 27-44. [CrossRef]

55. Barberà, S. Strategyproof social choice. In Handbook of Social Choice and Welfare; Arrow, K.J., Sen, A., Suzumura, K., Eds.; Elsevier: Oxford, UK, 2011; Volume 2, pp. 731-831. [CrossRef]

56. Sprumont, Y. The division problem with single-peaked preferences: A characterization of the uniform allocation rule. Econometrica 1991, 59, 509-519. [CrossRef]

57. Barberà, S.; Jackson, M.O.; Neme, A. Strategy-proof allotment rules. Games Econ. Behav. 1997, $18,1-21$. [CrossRef]

58. Goetz, R.-U.; Martinez, Y.; Rodrigo, J. Water allocation by social choice rules: The case of sequential rules. Ecol. Econ. 2008, 65, 304-314. [CrossRef]

59. Dirección General del Agua; Centro de Estudios Hidrográficos. Síntesis de los Planes Hidrológicos Españoles Segundo Ciclo de la DMA (2015-2021); Ministerio para la Transición Ecológica: Madrid, Spain, 2018.

60. Estrela, T.; Sancho, T.A. Drought management policies in Spain and the European Union: From traditional emergency actions to drought management plans. Water Policy 2016, 18, 153-176. [CrossRef]

61. Giannoccaro, G.; Castillo, M.; Berbel, J. Factors influencing farmers' willingness to participate in water allocation trading. A case study in southern Spain. Span. J. Agric. Res. 2016, 14, e0101. [CrossRef]

62. Palomo-Hierro, S.; Gómez-Limón, J.A.; Riesgo, L. Water markets in Spain: Performance and challenges. Water 2015, 7, 652-678. [CrossRef]

63. Montilla-López, N.M.; Gutiérrez-Martín, C.; Gómez-Limón, J.A. Water banks: What have we learnt from the international experience? Water 2016, 8, 466. [CrossRef]

64. Levy, P. Which right is right: The Pueblo water rights doctrine meets prior appropriation. Nat. Resour. J. 1995, 35, 413-434.

65. Hughes, R.W. Pueblo Indian water rights: Charting the unknown. Nat. Resour. J. 2017, 57, $219-262$.

66. Blumm, M.C. Federal reserved water rights as a rule of law. Ida. Law Rev. 2019, 52, 369-386.

67. Burness, H.S.; Quirk, J.P. Appropriative water rights and the efficient allocation of resources. Am. Econ. Rev. 1979, 69, 25-37.

68. Li, M.; Xu, W.; Rosegrant, M.W. Irrigation, risk aversion, and water right priority under water supply uncertainty. Water Resour. Res. 2017, 53, 7885-7903. [CrossRef]

69. Libecap, G.D. Institutional path dependence in climate adaptation: Coman's "some unsettled problems of irrigation". Am. Econ. Rev. 2011, 101, 64-80. [CrossRef] 
70. Huffaker, R.; Whittlesey, N.; Hamilton, J.R. The role of prior appropriation in allocating water resources into the 21st century. Int. J. Water Resour. Dev. 2000, 16, 265-273. [CrossRef]

71. Shi, T. Simplifying complexity: Rationalising water entitlements in the southern connected river Murray system, Australia. Agric. Water Manag. 2006, 86, 229-239. [CrossRef]

72. Wheeler, S.A.; Zuo, A.; Hughes, N. The impact of water ownership and water market trade strategy on Australian irrigators' farm viability. Agric. Syst. 2014, 129, 81-92. [CrossRef]

73. Zuo, A.; Ann Wheeler, S.; Adamowicz, W.L.; Boxall, P.C.; Hatton-MacDonald, D. Measuring price elasticities of demand and supply of water entitlements based on stated and revealed preference data. Am. J. Agric. Econ. 2015, 98, 314-332. [CrossRef]

74. Zuo, A.; Nauges, C.; Wheeler, S.A. Farmers' exposure to risk and their temporary water trading. Eur. Rev. Agric. Econ. 2014, 42, 1-24. [CrossRef]

75. Hughes, N.; Gupta, M.; Rathakumar, K. Lessons from the Water Market. The Southern Murray-Darling Basin Water Allocation Market. 2000-01 to 2015-16; Australian Bureau of Agricultural and Resource Economics and Sciences (ABARES): Canberra, Australia, 2016.

76. Grafton, R.Q.; Horne, J. Water markets in the Murray-Darling Basin. Agric. Water Manag. 2014, 145, 61-71. [CrossRef]

77. $\mathrm{Xu}, \mathrm{W} . ;$ Lowe, S.E.; Adams, R.M. Climate change, water rights, and water supply: The case of irrigated agriculture in Idaho. Water Resour. Res. 2014, 50, 9675-9695. [CrossRef]

78. Bjornlund, H. Farmer participation in markets for temporary and permanent water in southeastern Australia. Agric. Water Manag. 2003, 63, 57-76. [CrossRef]

79. Young, M.D.; McColl, J.C. Robust reform: The case for a new water entitlement system for Australia. Aust. Econ. Rev. 2003, 36, 225-234. [CrossRef]

80. Noussair, C.; Porter, D. Allocating priority with auctions: An experimental analysis. J. Econ. Behav. Organ. 1992, 19, 169-195. [CrossRef]

81. Hernández-Mora, N.; Del Moral, L. Developing markets for water reallocation: Revisiting the experience of Spanish water mercantilización. Geoforum 2015, 62, 143-155. [CrossRef]

82. García-Mollá, M.; Ortega-Reig, M.; Boelens, R.; Sanchis-Ibor, C. Hybridizing the commons. Privatizing and outsourcing collective irrigation management after technological change in Spain. World Dev. 2020, 132, 104983. [CrossRef]

83. Bakker, K. From state to market?: Water mercantilización in Spain. Environ. Plan. A 2002, 34, 767-790. [CrossRef]

84. Del Moral, L.; van der Werff, P.; Bakker, K.; Handmer, J. Global trends and water policy in Spain. Water Int. 2003, 28, 358-366. [CrossRef]

85. López-Gunn, E.; Ballesteros, M.; De Stefano, L.; Garrido, A.; Hernández-Mora, N.; Willaarts, B.A. Water security or water 'securities'? Increasing complexity in balancing of multiple goals in Spain. In Handbook on Water Security; Pahl-Wostl, C., Bhaduri, A., Gupta, J., Eds.; Edward Elgar Publishing: Cheltenham, UK, 2016. [CrossRef]

(C) 2020 by the authors. Licensee MDPI, Basel, Switzerland. This article is an open access article distributed under the terms and conditions of the Creative Commons Attribution (CC BY) license (http://creativecommons.org/licenses/by/4.0/). 